\title{
Migration and its Effects on Economic and Demographic Development in Romania ${ }^{1}$
}

\author{
Tatiana-Roxana Nae \\ Bucharest University of Economic Studies, Romania \\ E-mail: roxana.nae@com.ase.ro
}

Doi:10.5901/mjss.2013.v4n2p35

\begin{abstract}
The aim of the paper is to bring into attention migration theme, which although has echoes in the economic, demographic and social environments, it still needs effective policies. While official data are missing, providing research data about intentions and determinants of potential Romanian emigrants may lead to anticipated policies reactions and better oriented ones. The body of the paper particularizes the findings of an exploratory research on intention to emigrate from Romania of highly educated people, and analyzes some of the significant association relations between intention of emigration and its determinants. Methodological speaking, the research was organized as a survey based on a questionnaire, with respondents aged 20-40. The objective was to explore migration in order to find out more about the realities of migration phenomenon, about its causes and implications, and to detect significant association relations between intention of emigration and other variables. As results, five association relations were identified as being significant using nonparametric chi-tests. As conclusions, the duality of past and future economic and sociodemographic effects of migration for Romania but also for receiving countries is discussed while connecting to the fact that people perceptions and criticism regarding labor market might shape their future attitude regarding the decision of emigration.
\end{abstract}

\section{Introduction}

Since 2007, the free access to the European labor market made Romania to be more a sending country than an immigration one. If before this year it was easy to count permanent and non-permanent migrant people, starting with this year, the statistic system was in front of a methodological problem and degenerated in lack of information not only about numbers of migrants but also in missing data about the real number of inhabitants in the country and therefore, other structural indicators. An adapted and better set census survey from October 2011 (done once in ten years) by National Institute for Statistics is hoped to deliver by the end of 2012 more data regarding the above mentioned aspects. Meanwhile, interested actors in migration try to estimate the numbers but also the consequences of people movements. By the end of 2008, Romanians were second in the top of most numerous groups of foreign citizens resident in the European Union Member States, with a share of $6.2 \%$ of EU total foreign population (main destination countries being Italy and Spain, with about 1600000 Romanian migrants stock in 2010). In 2008 the EU27 Member States received 384 000 Romanian citizens, 266000 Polish citizens and 91000 Bulgarian citizens (Migrants in Europe, 2011 - published by Eurostat). Some evidences show great discrepancy between national statistics, the image that public opinion or media are projecting regarding this and the problems that destination countries confront to.

\section{Relevant theories of migration effects' nature}

Analyzing the characteristics of Romanian migration, labor emigration being the specific determinant of it, the effects for Romania as origin country and for destination countries may be discussed through changes in economy, demography and in society during past period but also through envisaged future changes. Anyway, these types of changes are linked and often examined together, as Katseli names some effects transmitted through communication channels of migration: growth, poverty, incomes distribution and social effects (Katseli, 2006). These are general terms which have specific

${ }^{1}$ Paper supported by funds from ERSTE Foundation Vienna, through the program Social Development, Generations in Dialogue Fellowship for Social Researchers. 
meanings for every country, depending on its profile. Both positive and negative effects occur for both origin and destination countries. Origin countries claim that they invest in skills development of persons that left the country, leading to a gap in economy but also in society, seen most in the long run. These deprivations may have negative effects on labor market and on economic development in origin countries, when policies are not correlated with real world of migration. But remittances are well known for their benefic role.

Migration effects are seen more in terms of economic and social aspects and less commented from the demographic point of view. Some recent theories on the subject of impact of migration on economic and social development are those of Ratha et al (2011), who highlights the positive effects on the migrant households, on the sending countries as well as the receiving countries.

Labor migration is perceived to be a response to poverty, a reaction to relative deprivation (Quinn, 2006). Literature in the field suggests that economic crises in origin countries may increase remittance transfers (Blue, 2004). We must understand that although public opinion is that immigrants might be responsible for rising unemployment of native population, there is no serious evidence in this respect, as literature shows (Papademetriou et al, 2009). Regarding the high-skilled emigration, literature often mentions that the phenomenon can reduce the sending country's productive capacity (Ratha et al, 2011) or disturb the education and health sectors in small countries that face shortages of health workers (Docquier et al, 2010) - it is the case of Romania. High-skilled migration should first be seen as a symptom of development failure rather than the cause of this failure (Lowell and Findlay 2002). Beside this, it is difficult to measure highly-skilled migration flows due to a lack of internationally comparable data (Auriol and Sexton, 2002), so this segment of the phenomenon is hard to be rigorous analyzed.

Regarding the preoccupation of Romania for this theme, while international community speaks about Romanians' migration, in our country there are few studies regarding migration dimensions and causes (Alexe, 2009; Sandu, 2007; Ghețău, 2007) or labour force connection to migration (Ailenei, 2009; Șerban and Toth, 2007, Sandu et al, 2004 and 2010).

\section{Migration effects on economic development}

For destination countries, Romanian migratory labor force produces economic impacts through: covering the demand for work in certain sectors and maintaining the profitability of these sectors; hiring people in sectors which are less profitable but necessary, permitting in this way that native skilled workers to be hired for jobs with high productivity.

The low and middle-income countries register, according to OECD, significantly higher remittances flows than other countries. Remittances are an important source of income in Romania as income from remittances in this country is larger than in any other country in EU, related to GDP (European Commission, Mobility in Europe, 2010). The downturn in economic activity in main host countries is shown in a reduction of inward remittance flows in Romania, in 2009 and 2010. The decreasing trend was present also for outward remittances flows.

Because migrants use also unofficial channels for remitting, total real remittances, both inward and outward, are believed to be much higher. In 2009 Romania was ranked by OECD second in top, with 255 thousands people who left the country, going in OECD countries but it was the first on top with its 12,000 emigrants per million population in the same year (International Migration Outlook, OECD, 2011). Although Romania has not the greatest amounts of people leaving the country (in absolute numbers), it has large amounts of remittances, being considered as part of the group of countries that sends temporary emigrants, and receives high levels of income remittances, along with Bulgaria, Lithuania, Slovakia and Poland. When remittances are converted into Romanian national currency, an appreciation of this is possible but knowing that inflows are used for purchasing imported goods, the deficit in the trade balance sheet is also present. The migration is reflected also in a direct way in Romanian balance sheet of payments.

Of course that by staying in the country, the migrants wouldn't have earn the same amounts of money and it would have occurred an underutilization of their labor force or even greater unemployment rates, so migration is rather preferred instead of its absence. Most of the effects generated through remittances are positive for Romanian economy but policy measures should be implemented in order that remittances to be rationally and efficiently allocated to investments, savings and consumption. As EU received in the last ten years great cohorts of migrants, this mobility had generally speaking a positive impact on EU's growth and it is pretty logically because people went were they were better paid, and were they could better work and use their skills, being more productive. In this framework, the migration of Romanians and Bulgarians during 2004-2007 determined an increase of $0.15 \%$ in the short run and $0.27 \%$ in the long run in EU's GDP, in the same period (Barrel et al, 2007 and Blanchflower et al, 2007). 


\section{Migration effects on societal and demographic development}

In the case of Romanian migration, some societal and individual effects are also envisaged by difficulties of people to maintain their family relations, their friend and their cultural heritage. National media often presents stories about left behind children of migrants who are living without parents' closeness and care. Social effects are more complex than these and affect not only the sending countries but also the destination ones. The immigrants who came into the host countries, although increase their standards of living, they often do not make it in having the same well-being of their family as natives have and they still keep as a stigma the fact that they come from poorer sending countries. When it is about certain ethnic migrants, discrimination occurs, as a consequence of the fact that Roma community is believed will deteriorate culture and will increase criminality. In such an environment some individual frustrations are highly probable to appear, both for natives and for migrants and for society in general.

If the economic consequences of Romanians migration are not so easy to be observed by public (but they will shape the long run development), the social and the demographic effects are already seen in the decrease of Romania's population from 23.2 millions in 1990 to 21.4 millions in 2011 but also in terms of aging and in the decrease of births. And the migration is not ending and is not decreasing in EU; it will shape societies more than it has done it until now. The phenomenon increased in EU rich countries and in EU in general and the states should be prepared for receiving migrants and have policies that can enable the positive effects of migration and integration measures.

The demographic aging and reduced birth rate will have negative effects especially for labor markets (in numbers and structure), for education system, and for budget and social security system in Romania. Eurostat forecasts a continuous growth of population aging for EU's states. Romania's population decreased during the last two decades from 23.2 millions inhabitants in 1990 to 2.14 millions inhabitants in 2009 and 2010 and forecasts are showing that this trend will continue. The birth rate also dropped from $13.7 \%$ in 1990 to $10 \%$ in 2008 while the average age of mother at first birth increased from 22.3 in 1990 to 26 years old in 2008, according to Romanian National Institute for Statistics.

In Romania, the demographic issue was also the main determinant of changing the pension system by introducing the private pillar. The decrease of population is not the worst evolution, but the continuous precarious structure on age groups, which will lead to disequilibrium in social and economic spheres. In Eurostat projections old age dependency rate will terribly increase from $25.4 \%$ in 2008 to $52.55 \%$ in 2060 for EU-27 countries and from $21.3 \%$ in 2008 to $64.77 \%$ in 2060 in Romania. So the main implication is that besides the population aging, the concern must be centered on labor market aging. In Romania the main emigration age group is 26-40 years old (which is part of working age population), according to Romanian National Institute for Statistics - it must be mentioned that data are referring to permanent migrants registered. The fact that most of the people who left Romania during 1990-2008 were aged 26-40 will have future demographic consequences. The greatest percentage of emigrants aged 26-40 was registered in $2005,58 \%$ from all emigrants but the levels of emigrants from this age category was also high in the next period $57.7 \%$ in $2006,56 \%$ in 2007 and $54 \%$ in 2008

\section{The case of a group of potential people who may soon leave Romania}

\subsection{The rationality and methodological aspects of studying intentions of migration}

Looking through economic and socio-demographic lens it is obvious that more information about migratory phenomenon can result into better shaped policies. Studies about intentions of migrations (Zaiceva and Zimmermann, 2008; Blanchflower, 2007) presented the importance of using intentions data. Eurobarometers data were frequently used by researchers, in order to complete the migration portrait. Generally, the impacts of migration depend on the flows and structural composition of migrant people and also of the functioning of the economies, in the sending and in the receiving countries. EU receives more and more migrants and also needs to know what kind of people are the potential migrants from one state into another. In a paper with provisional character from 2008, Zaiceva and Zimmermann identified the potential migrants in EU states as "to be young, better educated and to live in larger cities" (Zaiceva and Zimmermann, 2008). While migration data are missing, providing data about intentions and determinants of potential Romanian emigrants may lead to anticipated policies reactions and to better oriented ones.

The people that are subject of this research are the most vulnerable category of Romanians in terms of emigration vulnerability: aged 20-40 and highly educated, with at least university degree. They are considered potential migrants because they are part of the active population, highly educated and interested to apply their knowledge on labor force field which might or not be prepared to integrate them. In Romania, tertiary education attainment is higher for two age 
groups: $25-34$ (20.6\% in 2010$)$ and $35-44$ (13.4\% in 2010); the tertiary education attainment is the percentage of people of a given age class having attained tertiary education level and in Romania these structures were determined by the past education policy.

An exploratory research regarding the intention of emigration was used with the aim of finding out the main specific reasons that determine the mentioned category to emigrate or to stay in the country. Methodological speaking, the research was organized as a survey based on a questionnaire with 15 questions (28 variables included), with respondents selected through snow-ball method (nonprobilistic selection method). The research does not aim to be representative for the entire population as it may be impossible because of the missing data and because organizational reasons; the intention was to explore migration problem in order to find out more about the realities of migration phenomenon and about its causes. The questionnaire was filled in individually by 256 subjects living and working in Bucharest, in 2011.

\subsection{Research objectives and hypotheses of the study}

The assumption was that the emigration intention exists in the group of those aged 20-40 and having at least university degree. The assumption took into account that the young population has a great intention to emigrate, as Eurobarometer data also showed, and used some findings of a previously pilot research of 114 respondents with an average age of 23.5, made by the author in the spring of 2011. Regarding the construction of the group of reasons for emigration and for none migration intention the hypotheses were based on the push and pull factors stated by World Bank (World Bank, 2007). The main objectives of the research referred to: characterizing the collectivity from the point of view of age, occupational status (field of labor market), incomes etc; obtaining information regarding intention of permanent emigration in the next 3 years and temporary emigration in the next 5 years; identifying the most important reasons which determine emigration of questioned people and the most important reasons that determine them to stay in the country; analyzing the opinions of respondents regarding the Romanian labor force market; identifying and analyzing significant association relations between the groups of reasons for leaving Romania or for staying in the country and the intention emigration, and also between emigration intention and other variables, like opinion about labor market.

\subsection{Analysis of the exploratory research results}

The total number of people who filled in the questionnaire and in the same time complied the study and age criteria was 256 (the ones who did not met these criteria or left missing values in the questionnaire, were excluded from the discussed sample). The first part of the questionnaire permitted a brief characterization of the respondents group. SPSS software was used for analyzing the collected data. For a clear image and for further discussions reference, the distribution by age groups and gender can be seen in the table 1. From all the respondents, 208 persons were employed, 14 unemployed and 34 either self-employed or in another situation. Regarding study level, 49.2\% were university graduates, 47.7 were masters and 3.1 hold a doctoral degree. Most of them being aged 30-40 years, had incomes greater than 500 Euros per month, while their working fields were especially financial and assurance activities (14.1\%), real estate transactions $(12.5 \%)$, constructions (11.7\%) and trade activities (10.2\%).

Table 1: Distribution by age groups and gender

\begin{tabular}{|c|c|c|c|c|}
\hline \multicolumn{2}{|c|}{$\begin{array}{c}\text { Age * Gender } \\
\text { Crosstabulation }\end{array}$} & \multicolumn{2}{c|}{ Gender } & \multirow{2}{*}{ Total } \\
\cline { 2 - 4 } & $20-24$ & 20 & 4 & 24 \\
\cline { 2 - 5 } & $25-29$ & 34 & 24 & 58 \\
\cline { 2 - 5 } Age groups & $30-34$ & 84 & 30 & 114 \\
\cline { 2 - 5 } & $35-40$ & 36 & 24 & 60 \\
\hline \multicolumn{2}{|c|}{ Total } & 174 & 82 & 256 \\
\hline
\end{tabular}

Source: Author's calculations using SPSS 
Because of the specificity of Romanian migration, the questionnaire distinguished between temporary migration and the permanent one, in order to see potential migrants' perspectives in time. $30.5 \%$ of people that answered the questions have a certain intention to permanent migrate from Romania in the next three years, while the total percent of those who manifested very high and high probability intention of temporary migration in the next five years is higher up to $49.9 \%$ (Table 2).

Table 2: Intention of permanent and temporary migration

\begin{tabular}{|c|c|c|c|}
\hline \multicolumn{2}{|c|}{ Intention of permanent migration in the next three years } & Frequencies & Percents \\
\hline \multirow{4}{*}{ Answers } & Yes, for sure & 78 & 30.5 \\
\cline { 2 - 4 } & No, for sure & 114 & 44.5 \\
\cline { 2 - 4 } & Possible & 64 & 25.0 \\
\cline { 2 - 4 } & Total & 256 & 100.0 \\
\hline Intention of temporary migration for work in the next five years & Frequencies & Percents \\
\hline \multirow{4}{*}{ Answers } & Very high probability & 33 & 12.9 \\
\cline { 2 - 4 } & High probability & 69 & 27.0 \\
\cline { 2 - 4 } & Low probability & 46 & 18.0 \\
\cline { 2 - 4 } & Improbability & 108 & 42.1 \\
\cline { 2 - 4 } & Total & 256 & 100.0 \\
\hline
\end{tabular}

Source: Author's calculations using SPSS

Regarding the push and pull factors, because the ones that filled the questionnaire were young, it was expected that they will be more oriented to self-accomplishment as Fargues (2011) explains so a special attention was given to this aspect when questions regarding the determinants of migration were developed. The classification made by respondents revealed that from all detailed reasons for staying in Romania, the most important one is their fear regarding the difficulty in finding a job abroad according to their skills (reason scored 3.39) and then the perceived discrimination that they may encounter on the abroad labor force market (reason scored 3.35). Reasons for leaving Romania were: not finding a job, the possibility of a greater income from abroad job, bad job conditions and international career (Table 3).

Table 3: Descriptive statistics of reasons for leaving and not leaving Romania

\begin{tabular}{|l|c|c|c|c|c|}
\hline Reasons for not leaving Romania & $\mathrm{N}$ & Minimum & Maximum & Mean & Std. Deviation \\
\hline $\begin{array}{l}\text { Difficulty in finding a job abroad } \\
\text { according to skills }\end{array}$ & 256 & 1 & 5 & 3.39 & 1.634 \\
\hline Labor discrimination abroad & 256 & 1 & 5 & 3.35 & 1.250 \\
\hline Lack of financial resources & 256 & 1 & 5 & 2.98 & .907 \\
\hline Personal reasons, health and others & 256 & 1 & 5 & 2.97 & 1.394 \\
\hline Not knowing the language & 256 & 1 & 5 & 2.32 & 1.513 \\
\hline Reasons for emigrate from Romania & $\mathrm{N}$ & Minimum & Maximum & Mean & Std. Deviation \\
\hline Not finding a job & 256 & 1 & 5 & 3.85 & 1.234 \\
\hline A greater income from abroad job & 256 & 1 & 5 & 3.30 & 1.292 \\
\hline Bad job conditions at the present job & 256 & 1 & 5 & 3.24 & .892 \\
\hline International career & 256 & 1 & 5 & 2.84 & 1.675 \\
\hline Reuniting the family abroad & 256 & 1 & 5 & 2.00 & 1.099 \\
\hline
\end{tabular}

Source: Author's calculations using SPSS 
The most important objective of this exploratory research was to find significant association relations between push and pull factors Romanian migration and the intention of emigration (temporary and permanent one). Because the sample was not representative and data do not all met the normality conditions from statistical point of view, in stead of using ANOVA or other parametrical tests, nonparametric chi-tests were used, after verifying the preconditions for applying these.

From all analyzed relations the most significant are presented in turn in the appendix. The null hypothesis $\left(H_{0}\right)$ was that there was not a significant association relation between the variables, while $H_{1}$ was that the association relation was significant. Table 4 contains the association indicators and the intensity ones for five analyzed relations. In all presented relations, $H_{0}$ was rejected $H_{1}$ approved as all five relations were significant from statistic point of view. As it can be seen, intensity indicators of the associations are high except the last case between the variables "Intention of temporary emigration for work" and "Opinion about the fact that low incomes determine working abroad".

Table 4: Association relations between emigration intention and selected determinants

\begin{tabular}{|c|c|c|c|c|}
\hline $\begin{array}{l}\text { Association } \\
\text { relations }\end{array}$ & $\begin{array}{c}\text { Chi-Square } \\
\text { value }\end{array}$ & $\mathrm{df}$ & Asymp. Sig (2-sided) & Intensity of the association $\left(\varphi^{2}\right)^{b}$ \\
\hline Relation 1 & 77.105 & 12 & .000 & $\begin{array}{c}0.5488 \\
(0.3013)\end{array}$ \\
\hline Relation 2 & 63.871 & 12 & .000 & $\begin{array}{c}0.4994 \\
(0.2494)\end{array}$ \\
\hline Relation 3 & 92.161 & 8 & .000 & $\begin{array}{c}0.6000 \\
(0.3600)\end{array}$ \\
\hline Relation 4 & 86.187 & 12 & .000 & $\begin{array}{c}0.5802 \\
(0.3366)\end{array}$ \\
\hline Relation 5 & 31.301 & 9 & .000 & $\begin{array}{c}0.3496 \\
(0.1222)\end{array}$ \\
\hline
\end{tabular}

a. Relation 1 is between the variables "Intention of temporary emigration for work" and "International career importance as emigration cause".

Relation 2 is between the variables "Intention of temporary emigration for work" and "A greater income from abroad job as emigration cause".

Relation 3 is between the variables "Intention for permanent migration" and "Importance of difficulty in finding a job abroad according to their skills".

Relation 4 is between the variables "Intention of temporary emigration for work" and "Opinion about labor market capacity to hire all persons with university degree".

Relation 5 is between the variables "Intention of temporary emigration for work" and "Opinion about the fact that low incomes determine working abroad".

b.

$$
\varphi=\sqrt{\frac{\chi_{\text {computed }}^{2}}{N}}
$$

Source: Author's calculation using SPSS.

The conclusions regarding the analyzed relations must be interpreted and accepted as this experimental research has a psychological context. Regarding the first two associations, they represent the connection between the temporary emigration for work and two of the emigration motives: $30.13 \%$ of the decision of temporary emigration for work is related to importance of international career as emigration cause for respondents, while $24.94 \%$ of the intention for temporary emigration for work is associated to a greater perceived income from abroad job as emigration cause. The associations between the other identified emigration causes and temporary emigration were not significant. The association with the highest intensity $(0.60)$ is the one between intention of permanent migration and the importance of difficulty in finding a job abroad according to migrants' skills. The fear that their skills might not be recognized abroad is related to the intention 
of permanent migration of this group because they are highly educated and skilled and their expectations are to use competencies in their work and not to have any kind of job.

The last two associations show that the migration for temporary emigration is also related to opinions about labor market capacity to hire all persons with at least university degree (association with high intensity of 0.58 ) and the opinion about the fact that low incomes determine working abroad (although the relation is significant it is not intense, the effect of this opinion being very low, although many of the people approved the idea according to which low incomes in the origin country determine persons working abroad).

The opinions of respondents about labor market in general concluded to the perception of the vulnerability of the Romanian labor market and also to the fact that they are convinced that youth will soon migrate from Romania, due to economic and social causes. Being asked about integration chances, the most important aspects were for them: "the existence of working contract before leaving Romania" (average score of 9.21 from a maximum possible score of 10) and "having connections, friends or relatives abroad" (average score of 7.37 from a maximum possible score of 10). UK, Canada, USA, Italy and Spain were the wanted destination countries of this group so knowing the respondents' perceived requirements for integration, the authorities both from Romania and destination countries may implement policies including these aspects, in order to better and effective shape the migratory phenomenon.

\section{Conclusions and policy interactions}

The exploratory research results from above are specific for the group of questioned people and they can not be generalized for all potential migrants; the pilot research on a younger sample showed different results, but significant association relations were also present with other intensities. Nevertheless, economic and non-economic factors were associated with the intention of permanent or temporary emigration of highly educated group in both cases. While economics generally explained individuals' decisions to migrate through the cost-benefit analysis, in the present, migration is supposed to be more complex and not driven and associated only with income aspects, as we saw in the case of highly educated people from the above case. Their intention to migrate or not and the associated causes suggests that their motivations are more diverse and do not all concentrate on wage factor. Their perceptions and criticism regarding future labor market, in the context of a psychological experiment are important because these might shape their future attitude regarding the decision of emigration. Further research directions can be followed by Romanian authorities in order to have representative results about intentions of emigration for every segment of the population, in terms of age, educational background and other structural criteria.

We confront today with an economic crisis but also with a social one. If the crisis persist in EU' member states, it is possible that some political barriers to be used by some states in order to select the best migrants. If these will be shaped together with policies for facilitating the integration of migrants in the destination countries, they will bring effective results for receiving countries but also for individuals and origin countries. Romania, as origin country of many migrants, should better know its emigrants. Having data about the potential flows, structural composition of potential emigrants and determinants of Romanians' intention to emigrate may bring benefits from economic, social but also political point of view. Migration of highly educated people is a distinct segment of Romanian migration and estimations about the real effects that this emigration will have on demographic and economic development in Romania and in the host countries can only be done in the framework of pertinent and realistic policies. As it was commented in the above study, this group of highly educated people indicated as being very important for their integration abroad the existence of a working contract before leaving Romania and having connections with people that already live and work abroad. Their intention to emigrate was also reduced by the fear that they will not find a job abroad, according to their skills. As an option for controlling and also for using labor migration of highly educated people for its benefit, Romania may use programs based on labor contracts with destination countries as partners but also other policies oriented on age, educational and professional backgrounds of migrants. In the above case the association relations between intention of emigration and opinions regarding labor market were characterized by high intensity; precarious labor force market may determine people never come back or never invest their remittances in the origin country, so migration policies should be correlated with the one on the labor market.

As a policy approach we must also think that it is possible for migrants to return home, especially in this turbulent economic environment which covers European Union Member States. In host countries, foreigners are in a less favorable situation with regard to their employment status, their social benefits, their house living. In this respect, as part of Europe 2020 strategy, the European Council adopted as one of its five main targets the promotion of social inclusion, through 
"the reduction of poverty, by aiming to lift at least 20 million people out of the risk of poverty or exclusion". Romania must think that possible return migrants should be treated and offered sufficient conditions in order to be socially included.

As a final conclusion, it is a clear fact that some countries and especially Romania need a better evidence system for international migration, not only for demographic reasons but also economic ones especially.

\section{References}

Ailenei D. et al., The correlation of inequality-behavioral models-economic and social cohesion (Corelaţia inegalităţi-tipuri comportamental- coeziuneeconomică şi socială), Academy of Economic Studies, Bucharest, 2009.

Alexe I. (coord.), The needs of information of immigrants in Romania, research report on European Community programme, "Solidarity and dealing of migrant flows", 2009, Available online at http://www.osf.ro/ro/fisier_acord_publicatii. php?publicatie=91.

Auriol L. and Sexton J., Human resources in science and technology: measurement issues and international mobility in OECD (Organisation for Economic Cooperation and Development), International Mobility of the Highly Skilled, 2002, OECD Proceedings, Paris.

Barrell R. et al, EU enlargement and migration: assessing the macroeconomic impacts, 2007, NIESR Discussion Paper no. 292.

Blanchflower D. et al, The Impact of the Recent Migration from Eastern Europe on the UK Economy, 2007, IZA Discussion Paper, no.2615.

Blue S.A., State policy, economic crisis, gender, and family ties: Determinants of family remittances to Cuba, 2004, Economic Geography, vol. 80, no. 1, p. 63-82.

Docquier F., Marchiori L. and Shen I-L., Brain drain in globalization: A general equilibrium analysis from the sending countries' perspective, 2010, CEPR Discussion Paper, No. 7682.

European Commission, Mobility in Europe 2010, Available online at: http://www.eurofound.europa.eu /pubdocs/2006/59/en/1/ef0659en.pdf.

Eurostat, Migrants in Europe: A statistical portrait of the first and second generation, 2011, accessed at: http://epp.eurostat.ec.europa.eu/cache/ITY_OFFPUB/KS-31-10-539/EN/KS-31-10-539-EN.PDF.

Fargues P., International Migration and the Demographic Transition: A Two-Way Interaction, International Migration Review, Volume 45, no. 3 (Fall 2011):588-614.

Gheţău V., Demographic decline and the future of Romania population. A perspective on Romanian population in 21st century, (Declinul demografic şi viitorul populaţiei României. O perspectivă asupra populaţiei României în secolul 21), National Institute for Economic Research, Demographic Research Center „Vladimir Trebici”, Publisher Alpha MDN, 2007.

Katseli L. T. et al., Effects of Migration on Sending Countries: What Do We Know?, OECD, Development Centre Working Papers 250, 2006.

Lowell L.B. and Findlay A., Migration of Highly Skilled Persons from Developing Countries: Impact and Policy Responses, 2002, International Labour Organization, Geneva, and United Kingdom Department for International Development, London.

OECD, International Migration Outlook: SOPEMI 2011, OECD Publishing, Available online at: http://dx.doi.org/10.1787/migr_outlook-2011-en.

Papademetriou D., Sumption M. and Somerville W., Migration and the Economic Downturn: What to Expect in the European Union, Transatlantic Council on Migration, Migration Policy Institute, 2009.

Quinn, M. A., Relative deprivation, wage differentials and Mexican migration." Review of Development Economics, 2006, vol. 10, no. 1 , p. 135-153.

Ratha D., Mohapatra S. and Scheja E., Impact of Migration on Economic and Social Development: A Review of Evidence and Emerging Issues, The World Bank - Development Prospects Group, Migration and Remittances Unit \& Poverty Reduction and Economic Management Network, Policy Research Working Paper 5558, 2011.

Romanian National Institute For Statistics data basis and Yearbooks 1990-2009.

Sandu D. (coord.), Temporary leaving abroad. Romanians economic migration: 1990-2006 (Locuirea temporară în străinătate. Migraţia economică a românilor: 1990-2006), 2007, Foundation for an Open Society (Soros Foundation), 2006, Available online at: http://www.soros.ro/ro/publicatii.php?pag=2.

Sandu D. et al, A country report on Romanian migration abroad: stocks and flows after 1989, study for Multicultural Center Prague www.migrationonline.cz, November 2004.

Sandu D. et al, Social worlds of Romanian migrations abroad (Lumi sociale ale migratiei romanesti in strainatate), Polirom Publisher, 2010.

Şerban M. and Toth A., The labor market in Romania and immigration, Soros Foundation, Bucharest, 2007.

World Bank, Migration and Remittances, edited by Mansoor A. and Quillin B., Wahshington, 2007.

World Bank, The Migration and Remittances Factbook 2011, Available online at: www.worldbank.org/prospects/ migrationandremittances. 
Zaiceva A. and Zimmermann K., Scale, Diversity, and Determinants of Labor Migration in Europe, 2008, The Institute for the Study of Labor, discussion paper no.3595.

\section{Appendix}

Table A: Chi-Square Tests for relations 1 to 4

\begin{tabular}{|c|c|c|c|c|c|c|c|}
\hline For relation 1 & Value & df & $\begin{array}{l}\text { Asymp. Sig. } \\
\text { (2-sided) }\end{array}$ & For relation 3 & Value & df & $\begin{array}{l}\text { Asymp. Sig. } \\
\text { (2-sided) }\end{array}$ \\
\hline Pearson Chi-Square & $77.105^{a}$ & 12 & .000 & Pearson Chi-Square & $92.16^{a}$ & 8 & .000 \\
\hline Likelihood Ratio & 79.798 & 12 & .000 & Likelihood Ratio & 97.745 & 8 & .000 \\
\hline $\begin{array}{l}\text { Linear-by-Linear } \\
\text { Association }\end{array}$ & 41.857 & 1 & .000 & $\begin{array}{l}\text { Linear-by-Linear } \\
\text { Association }\end{array}$ & 23.145 & 1 & .000 \\
\hline \multicolumn{4}{|c|}{$\begin{array}{l}\text { a. } 4 \text { cells }(20.0 \%) \text { have expected count less than } 5 \text {. The } \\
\text { minimum expected count is } 2.96 \text {. } \\
\text { b.For decision testing, Chi-Square for } d f=12 \text { and } p=0.05 \\
\text { is } 21.03 \text {, for } p=0.025 \text { is } 23.3 \text {, for } p=0.01 \text { is } 26.22 \text {. }\end{array}$} & \multicolumn{4}{|c|}{$\begin{array}{l}\text { a. } 3 \text { cells }(20.0 \%) \text { have expected count less than } 5 \text {. The } \\
\text { minimum expected count is } 1.75 \text {. } \\
\text { b.For decision testing, Chi-Square for } d f=8 \text { and } p=0.05 \text { is } \\
15.51 \text {, for } p=0.025 \text { is } 17.53 \text {, for } p=0.01 \text { is } 20.09 \text {. }\end{array}$} \\
\hline For relation 2 & Value & $\mathrm{df}$ & $\begin{array}{l}\text { Asymp. Sig. } \\
\text { (2-sided) }\end{array}$ & For relation 4 & Value & $\mathrm{df}$ & $\begin{array}{l}\text { Asymp. Sig. } \\
\text { (2-sided) }\end{array}$ \\
\hline Pearson Chi-Square & $63.871^{\mathrm{a}}$ & 12 & .000 & Pearson Chi-Square & $86.18^{a}$ & 12 & .000 \\
\hline Likelihood Ratio & 68.369 & 12 & .000 & Likelihood Ratio & 90.529 & 12 & .000 \\
\hline $\begin{array}{l}\text { Linear-by-Linear } \\
\text { Association }\end{array}$ & 45.185 & 1 & .000 & $\begin{array}{l}\text { Linear-by-Linear } \\
\text { Association }\end{array}$ & 58.619 & 1 & .000 \\
\hline \multicolumn{4}{|c|}{$\begin{array}{l}\text { a. } 4 \text { cells }(20.0 \%) \text { have expected count less than } 5 \text {. The } \\
\text { minimum expected count is } 2.32 \text {. } \\
\text { b.For decision testing, Chi-Square for } d f=12 \text { and } p=0.05 \\
\text { is } 21.03 \text {, for } p=0.025 \text { is } 23.3 \text {, for } p=0.01 \text { is } 26.22 \text {. }\end{array}$} & \multicolumn{4}{|c|}{$\begin{array}{l}\text { a. } 2 \text { cells }(10.0 \%) \text { have expected count less than } 5 \text {. The } \\
\text { minimum expected count is } 2.45 \text {. } \\
\text { b.For decision testing, Chi-Square for } d f=12 \text { and } p=0.05 \\
\text { is } 21.03 \text {, for } p=0.025 \text { is } 23.3 \text {, for } p=0.01 \text { is } 26.22 \text {. }\end{array}$} \\
\hline
\end{tabular}

Source: Author's calculations based on research results. 
